\title{
The State of the Infrastructure Environment as a Determining Factor of Heterogeneity in the Development of the Regions of Russia
}

\author{
Tatyana Tretyachenko, Galina Pivovarova*, and Svetlana Sogomonyan \\ Department of Commerce and Logistics, Rostov State University of Economics (RINH), 344002, B. \\ Sadovaya Str., 69, Rostov-on-Don, Russia
}

\begin{abstract}
The article is devoted to the issues of heterogeneity in the development of the infrastructure environment of macro-regional economic systems (federal districts) and their regions. An assessment of the state and effectiveness of the infrastructure environment in macroregions and regions of the Russian Federation is made, it is concluded that interregional heterogeneity in the provision of physical infrastructure and its state affects the functioning and development of both regional economic systems and the economic system of the state as a whole. It is emphasized that the priority of state policy in the development of the infrastructure environment of regions - leaders leads to the migration of labor to these regions, increases the burden on their budgets, further enhances asymmetric regional development, and contributes to the growth of social tension in regions with an insufficient and degrading infrastructure environment. The article presents data on per capita financing for the development of infrastructure of leading regions and outsider regions, the level of infrastructure development in the regional context. The authors propose to use such promising mechanisms as bonds and infrastructure crowdfunding to finance the development of infrastructure of leading regions.
\end{abstract}

\section{Introduction}

Russia's development in the conditions of transformation to the market economy gave rise to many serious problems, one of which was the gradual degradation of the infrastructure of most of its regions. Meanwhile, the presence of a developed infrastructure determines the country's place that it takes place in the world economic system, since it is a dominant factor in the development of the productive forces, a global market, creates the conditions of human life and determines the quality of his life. [1,2] (Hausmann R., Klinger B., Wagner R., 2008, Kuznetsova A.I.,2013). Today, Russia in the world ranking among the 131 countries in terms of infrastructure quality occupies 60 place, social spending per capita - 113 place, the quality of road infrastructure - 99 place, quality of health care - 97 place [3, 4] (World Economic Forum, 2019). The infrastructure modernization indicator for accelerating the energy transition and expanding access to electricity and ICT in

\footnotetext{
${ }^{*}$ Corresponding author: gbp@list.ru
} 
Russia is 57.21 points, and is estimated as the lowest among the 131 world economies. The total amount of infrastructure investments in 2020 amounted to 39.2 billion US dollars in Russia, per capita accounted for $\$ 268.6$, with the need of $\$ 420.1$, which is 3.5 times less than in the United States of America and 2.3 times less than in China (Fig. 1).

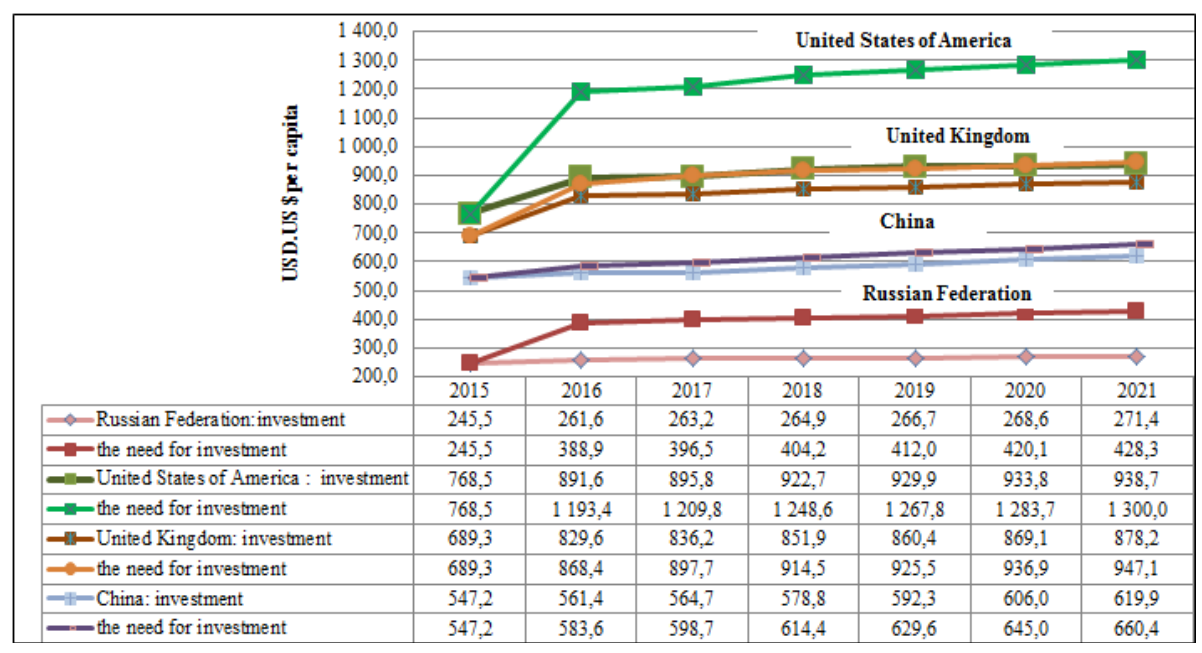

Fig. 1 Investing of the Russian Federation and some countries of the world in the development of infrastructure and the need for infrastructure investments for 2015 -2021, (National Center for PPP, 2020) [5].

Around the world, there is a significant shortage of funds allocated to infrastructure development, its volume according to the World Bank and Global Infrastructure Hub [6] for the next 20 years is estimated at 13 trillion US dollars. Closing the infrastructure financing gap is one of the most important and complex issues in the entire global infrastructure industry, which indicates the difficulty of achieving significant changes. Given the current and projected underfunding of the infrastructure needs of the economy, the issue of attracting investments in infrastructure development in Russia is no less acute than abroad: the deficit of infrastructure investments according to the calculations of Global Infrastructure Hub, OECD and the World Bank will amount to 1.5 billion US dollars for Russia during this period [7]. An additional problem of attracting funds for infrastructure development is that in the geographical horizon of Russia the state of the infrastructure environment does not represent a homogeneous environment. The current situation with insufficient provision of physical infrastructure in some regions of the country and redundancy in others, the poor quality of the infrastructure environment in the vast majority of regions, the uneven distribution of support for the infrastructure complex are a significant restriction on economic growth, their investment attractiveness (Fig. 2). 


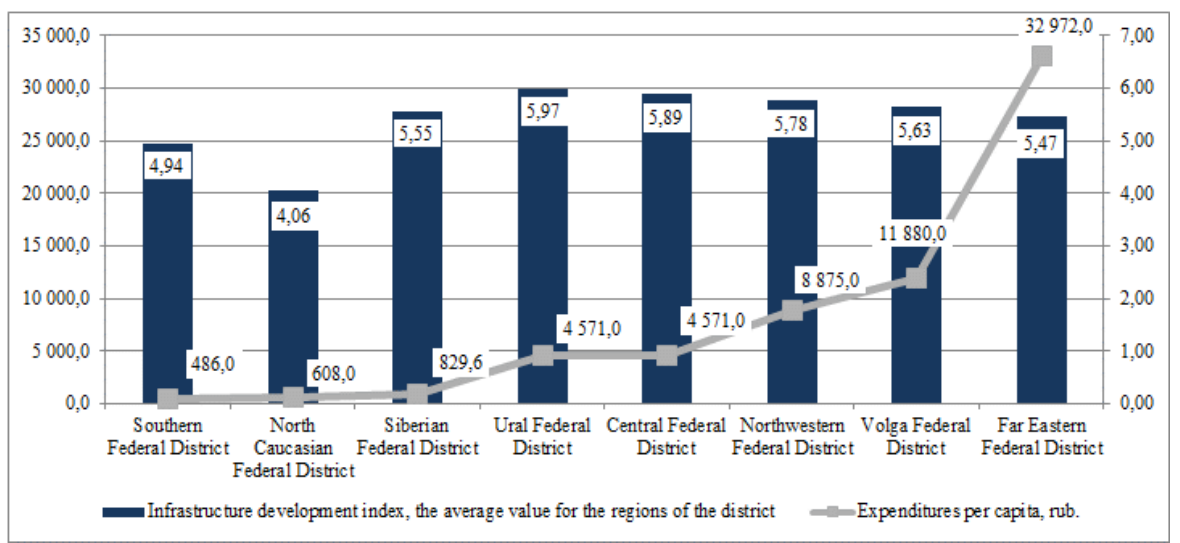

Fig. 2 Infrastructure Development Index, the volume of investments aimed at developing the infrastructure of federal districts for 2019-2020 (State Development Corporation VEB.RF, ANO "National Center of PPP", AECOM, 2020) [7].

Deepening differences in the infrastructure provision of the regions exacerbates the problems of imbalances in regional development, makes the issue of developing tactics and strategy for spatial infrastructure development of Russia even more urgent.

The problems of interregional asymmetry of the development of regions and their infrastructure environment remain debatable today, a common position has not been developed, in particular, on such issues as determining the optimal balance of stimulating and leveling measures, the priority of spatial leveling of Russia, effective methods of ensuring more equal access to public goods for people living in different macroregions and regions of the country and others [8] (Zubarevich, 2014). Since infrastructure is an environmental type of economic system and, in fact, acts as an internal or external environment of a socio-economic system of any level, the category of only "bad" or only "good" cannot be applied to it. The infrastructure environment cannot be completely new if it is even $100 \%$ artificial, since it is always created around a person who stores memory about the environment. Along with the new infrastructure elements, there will always be infrastructure facilities already created in other formations. These postulates form the basis of the present study and are taken into account by the authors in the analysis and assessment of the state of the infrastructure environment, which they define as a set of conditions, institutions and objects that determine the level of development of the economic system and characterize the state of its subsystems. The mechanism used in the country to finance projects for the development of regional infrastructure provides for the allocation of funds from the federal budget on a competitive basis and subject to its cofinancing by the subject of the Federation. Such a financing mechanism initially includes a system to curb the development of infrastructure, since only 13 out of 85 regions have a sufficient amount of their own financial resources [9] (Ministry of Finance of the Russian Federation, 2019). The purpose of this study is to analyze the heterogeneity of the development of the infrastructure environment of the regions and federal districts of Russia, reinforced by high risks and uncertainty of the consequences of the pandemic shock (COVID - 19). The authors formulated a hypothesis that the infrastructure as a subsystem of the socio-economic system of the region has a direct impact on the state of this system and, therefore, when investing in the development and modernization of the infrastructure of lagging regions, it is able to level out the imbalances in the development of regions, improving the quality of life of the population of the region.

This hypothesis has found a confirmation in this study. 


\section{Materials and Methods}

The impact of the growth of regional asymmetry in the provision and quality of the state of physical infrastructure to the degree of heterogeneity of the economic development of regions in the works of domestic and foreign authors in such a context was not investigated. Meanwhile, the role of infrastructure in stimulating the growth of the economy, its impact on the solution of the fundamental economic problems of the region was the subject of study of many foreign authors. (Rosenstein-Rodan P., 1944; Hirshman A., 1958; Jochimsen R., 1966; Isard W., 1966 [6-9] и др.) and domestic scientists (Terentyev V., 1979; Krasovsky V., 1980; Nosova P. 1984; Feodorites V., 1985; Golz G., 1989; Fedorov V., 2000; Mordovchenkov N., 2010, Kuznetsova A. 2013, Oshesshnikova, L., 2013, Litvinova Yu., Ponomarev Y., 2016 [10-16, 2, 17-18]). The first dependence of economic dynamics from the state of the infrastructure environment was established by D. Oshauer [19] (Aushauer D., 1989), in its assessment, only a 10 percent increase in the state in infrastructure investments leads to an increase in capital performance by $3-5 \%$, that is, the implementation Infrastructure projects leads to simultaneous intensification of activities in related industries, an increase in employment and workload in them. The conclusions of D. Oshauer were confirmed by research of Spanish scientists [20, 21] (Deno Kt, 1991, Cantos P., Gumbau A., Maudos J., 2005) Additional investments in the development of transport infrastructure as well as investments in the construction industry infrastructure lead to improving the productivity of the private sector. Relying on the results of research on infrastructure research, and conclusions that the infrastructure stimulates the growth of economic development, it is logical to assume that the leveling of disproportion in the infrastructure and provision of its objects contributes to the process of convergence of regions, providing them with equal opportunities for dynamic development due to access to Modern infrastructure objects. The authors resorted to such methods of scientific research, as a monographic review of publications on the topic of the article, the assessment of statistical data characterizing the state of the infrastructure environment of regions and macroregions, a logical analysis, a quantitative assessment of key performance indicators and modeling.

\section{Results and Discussion}

The infrastructure is an integrating organizational form of processes that occur at all levels of the socio-economic system, since it is identified with the internal environment of these systems. As an economic system of media type infrastructure contains interconnected and structured elements and subsystems, quality and security that determines the level of favorable of this environment. The infrastructure of multidimensional, systemic and acts as a condition for the development of the economy in all its spheres. There is an indirect relationship between the quality of the infrastructure environment of regions and the heterogeneity of their development. (table 1). 
Table 1. Data on ranks of the level of infrastructure development, socio-economic development and quality of life in the subjects of the Federation of Russia (regions occupying the first and last ten places on the importance of the integral index of infrastructure development, the average value of the country is 5.61) for 2020

\begin{tabular}{|c|c|c|c|c|c|c|}
\hline Region & $\begin{array}{c}\text { Integral } \\
\text { index of the } \\
\text { level of } \\
\text { infrastructure } \\
\text { development } \\
\text { in the } \\
\text { region* } \\
\end{array}$ & Rating & $\begin{array}{l}\text { Rating } \\
\text { assessment } \\
\text { of the socio- } \\
\text { economic } \\
\text { situation of } \\
\text { the regions }\end{array}$ & Rating & $\begin{array}{c}\text { Rating } \\
\text { assessmen } \\
t \text { of the } \\
\text { quality of } \\
\text { life }\end{array}$ & Rating \\
\hline Moscow & 7,77 & 1 & 88,98 & 1 & 82,164 & 1 \\
\hline Saint-Petersburg & 6,91 & 2 & 85,549 & 2 & 80,634 & 2 \\
\hline Moscow Oblast & 6,65 & 3 & 77,763 & 3 & 76,068 & 3 \\
\hline $\begin{array}{l}\text { Khanty-Mansi } \\
\text { Autonomous Okrug }\end{array}$ & 6,55 & 4 & 77,595 & 4 & 60,523 & 9 \\
\hline Irkutsk Oblast & 6,25 & 5 & 51,251 & 22 & 41,786 & 55 \\
\hline Belgorod Oblast & 6,19 & 6 & 76,544 & 5 & 64,769 & 5 \\
\hline Murmansk Oblast & 6,18 & 7 & 44,358 & 36 & 45,774 & 43 \\
\hline Sverdlovsk Oblast & 6,11 & 8 & 69,278 & 7 & 56,59 & 15 \\
\hline Krasnoyarsk Krai & 6,11 & 9 & 61,554 & 12 & 45,362 & 46 \\
\hline Republic of Tatarstan & 6,05 & 10 & 76,544 & 5 & 66,624 & 4 \\
\hline$\ldots$ & .. & $11-75$ & 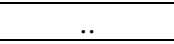 & .. & .. & .. \\
\hline Sevastopol & 5,05 & 76 & 29,874 & 64 & 54,249 & 19 \\
\hline Republic of Ingushetia & 5,01 & 77 & 16,279 & 82 & 31,452 & 78 \\
\hline Republic of Kalmykia & 4,94 & 78 & 17,361 & 80 & 33,12 & 76 \\
\hline $\begin{array}{l}\text { Republic of Sakha } \\
\text { (Yakutia) }\end{array}$ & 4,88 & 79 & 45,835 & 33 & 39,194 & 65 \\
\hline $\begin{array}{l}\text { Karachay-Cherkess } \\
\text { Republic }\end{array}$ & 4,88 & 80 & 16,763 & 81 & 27,693 & 83 \\
\hline Republic of Buryatia & 4,84 & 81 & 27,889 & 71 & 28,944 & 81 \\
\hline Altai Republic & 4,82 & 82 & 13,71 & 83 & 29,431 & 80 \\
\hline Chechen Republic & 4,71 & 83 & 28,373 & 68 & 36,754 & 74 \\
\hline Tuva Republic & 4,56 & 84 & 13,174 & 84 & 17,506 & 85 \\
\hline Republic of Dagestan & 4,06 & 85 & 34,731 & 57 & 41,261 & 56 \\
\hline
\end{tabular}

* Integral index of the level of infrastructure development in the region It is designed based on indicators on five subsystems of public infrastructure: transport (ITR), energy (IE), social (IS), communal (IK) and telecommunications (IT), which was discussed on the basis of calculating industry indices. The maximum possible value of the integral index - 10, which corresponds to the "ideal" developed region in all five subsystems. The calculation of private indexes ITR, IE, IS, IK, IT is calculated on the basis of the general formula:

$$
I=\frac{P_{f i x}-P_{\min }}{P_{\max }-P_{\min }}
$$

where $\mathrm{P}_{-}$FIX is the actual value of the indicator in the region, $\mathrm{P}_{-} \max , \mathrm{p} \_\mathrm{min}$ - the maximum and minimum value among all the regions under study.

$$
I_{\text {int }}=\frac{I_{t r}+I_{e}+I_{S}+I_{k}+I_{t}}{5} \text {. }
$$

Therefore, real investments aimed at the modernization and construction of buildings and structures, transportation system, social infrastructure not only regions leaders, but also recipients (in order to balance the physical infrastructure that performs the function of the foundation of economic development), positively and multiply can affect the 
development of the economy Regions, and, it means, and reduce the level of assimetric regional development.

At the same time, as global experience shows, investing in the quality infrastructure of the regions should be carried out taking into account their originality, the differentiation of production, the presence of problems related to the development of infrastructure, the state of management, since they influence the economic effect of infrastructure investments. For example, according to McKinsey experts, an increase in annual general infrastructure investments by $1 \%$ of GDP will create 3.4 million new jobs in India, 1.5 million places in the United States and 1.3 million jobs in Brazil [7].

The results of the studies conducted by the authors showed that the growth tactics and polarization points adopted in the domestic practice, when the priority of state policy focuses on the development of regions - leaders, which in theory should be the driver for the development of the entire domestic economy, worsens the situation with the spatial heterogeneity of the infrastructure environment, enhances the Territorial differentiation.

At the end of 2019, among all the subjects of the Federation, the value of the integral index of infrastructure development, the rating of socio-economic development and quality of life were leading Moscow (7.77), St. Petersburg (6.91) and the Moscow region (6.65). In the three regions with the lowest values of the index of the infrastructure of Chechnya (4.71), Tuva (4.56) and Dagestan (4.06).

Budget investments in the development of infrastructure at the end of 2020 amounted to almost 2.36 trillion. rub., or $2.2 \%$ of GDP. As part of budget investments, regional infrastructure investments amounted to more than $77.5 \%$. Regions Leaders received $26.39 \%$ of the total volume of infrastructure investments allocated in 2020: Moscow (467.30 billion rubles), St. Petersburg (71.60 billion rubles) and Moscow region (83.80 billion rubles. .), That per capita amounted to $36,478.3$ thousand rubles, respectively., $13,406.3$ and 9,339.7 thousand rubles. Back in two regions: Crimea (70.6 billion rubles) and Tatarstan (62.2 billion rubles), occupying 10 and 73 rods in the ranking in terms of infrastructure development, budget investments amounted to more than 50 billion rubles.

The investment of infrastructure development of the remaining 80 constituent entities of the Federation accounted for $59 \%$ of the allocated budget funds. At the same time, 43 of them received infrastructure budget investments in the amount of less than 10 billion rubles. In the Republic of Dagestan, which closes the rating of regions in terms of infrastructure development, regional infrastructure investments amounted to 8,002,96 thousand rubles. per capita or 4.6 times less than in the leading region (Moscow), despite the fact that the lag behind the state of the infrastructure of Dagestan from the rest of the regions for 2019 year increased (table 2).

Table 2. The volume of financial support for the development of infrastructure of regions leaders and regions-outsiders in 2020

\begin{tabular}{|c|l|r|r|r|r|}
\hline Rating & \multicolumn{1}{|c|}{ Region } & $\begin{array}{c}\text { Integral index } \\
\text { of the level of } \\
\text { infrastructure } \\
\text { development in } \\
\text { the region }\end{array}$ & $\begin{array}{c}\text { Optimal level } \\
\text { of } \\
\text { infrastructure } \\
\text { development }\end{array}$ & $\begin{array}{c}\text { Budget } \\
\text { expenditures on } \\
\text { infrastructure, } \\
\text { per capita, } \\
\text { thousand rubles }\end{array}$ & $\begin{array}{c}\text { Extra-budgetary } \\
\text { funds per capita } \\
\text { within the } \\
\text { framework of } \\
\text { project financing, } \\
\text { thousand rubles }\end{array}$ \\
\hline 1 & Moscow & 7,77 & 8,61 & 36478,3 & 10971,5 \\
\hline 2 & Saint-Petersburg & 6,91 & 7,92 & 13406,3 & 3956,4 \\
\hline 3 & Moscow Oblast & 6,65 & 8,00 & 9339,7 & 3248,4 \\
\hline $4 \ldots 82$ & $\ldots$ & $\ldots$ & $\ldots$ & $\ldots$ & $\ldots$. \\
\hline 83 & Chechen Republic & 4,71 & 5,71 & 14,9 & 4096,4 \\
\hline 84 & Tuva Republic & 4,56 & 6,41 & 4,7 & 4187,1 \\
\hline 85 & $\begin{array}{l}\text { Republic of } \\
\text { Dagestan }\end{array}$ & 4,06 & 5,69 & 24,9 & 2432,8 \\
\hline
\end{tabular}


The number of projects planned for implementation in the coming years is generally evenly distributed throughout the country: in each of the federal districts there are from 12 to 20 projects. The exception is the Southern Federal District, where, according to Infrane Research, only six projects can be launched, and the North Caucasian, which have no one [22].

The most capital-intensive projects are concentrated in the Central Federal Circle: on 14 projects of which account for $29.9 \%$ or 558.9 billion rubles. All investments (Moscow agglomeration concentrates 363.3 billion rubles. or $69.0 \%$ of the district), and the NorthWest Federal District, whose projects account for $15.1 \%$ or 281.7 billion rubles. All infrastructure investments (St. Petersburg absorbs 255.9 billion rubles with its 13 projects. or $90.84 \%$ of all districts of the district).

The key risks of asymmetric regional development are the further strengthening of the imbalances of the economic and social provisions of the regions, the migration of labor into the regions-leaders of innovation, increasing the burden on the budgets of donor regions, the growth of social tensions. In 2018, 91.2 million people lived in the regions with the index above the average Russian (5.70), or $62.1 \%$ of the country's population, and in 2019 - already 101.5 million people, or $69.1 \%$. In 2020, the number of "beneficiaries" among residents of 40 regions increased by almost 1.0 million people. In the subjects of the Federation with an infrastructure development index of less than 5.00, that is, characterized by a strong infrastructure lag from other regions, 7.8 million people lived in 2020 , or $5.3 \%$ of the country's population, which is 0.9 million people less than in 2019.

A decrease in the rise in regional differentiation in the conditions of budget constraints is possible through the involvement of a mass investor, that is, the ultimate benifies of infrastructure, in the implementation of small infrastructure projects with a high social meaning planned for implementation in regions leaders who have a high level of quality of life of the population (high income). In such regions, there are no obstacles to the creation of basic conditions of infrastructure crowdfunding: a digital platform, acting by an aggregator of investment proposals and / or payment gateway, as well as regulatory conditions for attracting funds for unskilled investors. Elevated investment resources will redirect to the implementation of infrastructure projects of regions-outsiders.

As the study showed, domestic and foreign investors are ready to direct up to 2 trillion to the development of the Russian infrastructure market. rub. per year [23]. However, their interest in such investments remains unfulfilled due to the insufficient transparency of the infrastructure market and the lack of effective assessment tools for investment decisions. Under these conditions, possible effects for the infrastructure market

There may be improved quality of projects and standards for their preparation and implementation.

\section{Conclusions}

The results of the study show that the infrastructure is the driving force of economic prosperity and the foundation for sustainable, balanced and inclusive growth and development, which are key goals and are crucial for regional development priorities. However, most regions continue to face an insufficient investment in a new and existing infrastructure, which is a serious obstacle to economic growth and development or guarantees of reliable state and regional services.

The current trend of the state of state to infrastructure is their critical low. Investments in infrastructure All last years did not exceed $\%$ of GDP with the minimum required level of $4.5-5.0 \%$ of GDP. According to Global Infrastructure Hub in the 
period 2021-2040, Russia will experience a lack in annual investments in infrastructure objects in the amount of $\sim 1.9 \%$ of GDP [4].

In the context of the restrictions caused by COVID-19, in 2020, the revenue part of 40 regional budgets did not reach the planned indicators, the volume of construction fell in 27 regions, and in 9 regions, infrastructure companies have observed a loss of revenue [22].

The projected indicators of the consolidated country's consolidated budget for the next three years show that already in 2021 it is possible to reduce the infrastructure expenses of budgets of all levels by $8.0-10.0 \%$ to the level of 2020 .

Against the background of the current economic situation, there is no potential for increasing the income of regional and municipal budgets, currently used the tactics of point priority state support for the infrastructure arrangement of regions - leaders may result in further strengthening of asymmetric regional development, degradation of outsider regions due to outflow of them economically active population.

Decrease the rate of increasing regional differentiation in a significant reduction in budgetary opportunities for the launch of new infrastructure projects, through the redistribution of infrastructure investments planned for regions leaders in the Outsiders regions. In this regard, it is necessary to introduce new project financing mechanisms that can attract additional extrabudgetary funds in the development of the infrastructure of regions leaders: perpetual bonds and infrastructure crowdfunding. financing. It is important to start developing an institutional environment and improve the examination in structuring transactions, raise the transparency of the market, form the best practices to apply project financing tools. This would improve interest, including institutional investors to project financing bonds.

This research would not be able to achieve without a support from of A. U. Albekov and Yu. S. Kolesnikov.

\section{References}

1. R. Hausmann, B. Klinger., R. Wagner, Doing Growth Diagnostics in Practice: A 'Mindbook', 177 (2008).

2. A.I. Kuznetsova, infrastructure: Questions of theory, methodology and applied aspects of modern infrastructure arrangement. Geeconomic approach, Yurait. (2013).

3. Klaus Schwab, Saadia ZahidiThe, Global Competitiveness Report Special Edition 2020: How Countries are Performing on the, Special ed it ion 2020. Retrieved from https:/www.weforum.org/reports/the-global-competitiveness-report-2020. (2020).

4. The Global Innovation Index 2020, Cornell University, INSEAD, and the World Intellectual Property Organization, 13TH EDITION 2020. Retrieved from https://www.wipo.int/edocs/pubdocs/en/wipo_pub_gii_2020.pdf (2020).

5. Investing of the Russian Federation and the world in the development of infrastructure, the National Center for PPP, the Rosinfra platform. Retrieved from https://rosinfra.ru/digest/investment. (2020).

6. Infrastructure Futures. The impact of megatrends on the infrastructure industry, Global Infrastructure Hub Ltd/ Retrieved from https://rosinfra.ru/files/analytic//document/f5c126925e61 cc7e6c14a0c1521b64e3.pdf. (2020).

7. Infrastructure for sustainable development. How to attract investments in the new quality of projects, the State Development Corporation VEB.RF, Ano National 
Center for PPP, AECOM. Retrieved from https:/вэб.pф/downloads/infrastructurefor-sustainability-web.pdf, март (2020).

8. N.V. Zubarevich, Regional Development and Regional Policy in Russia? Eco, 4. 7, (2014).H.B.

9. On approval of lists of the constituent entities of the Russian Federation in accordance with the provisions of paragraph 5 of Article 130 of the Budget Code of the Russian Federation, the order of the Ministry of Finance of RussiaRetrieved from https://minfin.gov.ru/, 1032, 15 ноября (2019).

10. P.N. Rosenstein-Rodan, The International Development of Economically Backward Areas, International Affairs. (1944)

11. Albert O. Hirschman, The Strategy of Economic Development. Yale University Press, New Haven, 10, 217 (1958).

12. Reimut Jochimsen Jochimsen R. Theorie der infrastruktur. Grundlagen der marktwitschaftlichen Entwicklun. (1966)

13. W. Isard., Methods of Regional Analysis: an Introduction to Regional Science, Прогресс (1966).

14. V. G. Terentyev, features of infrastructure development in different regimes of public reproduction, the problems of functioning and development of the infrastructure of the national economy. Proceedings of the seminar, 5 (1979).

15. V.P. Krasovsky, infrastructure and intensification of the economy, science (1980).

16. S. S. Nosova, Socialist infrastructure in the reproduction process, Economics (1984).

17. V.Ya. Feodorites, improving the structure of the national economy of the USSR, knowledge (1985).

18. G.A. Golz, a synergistic approach to the study of infrastructure dynamics in the settlement systems, the evolution of resettlement in the USSR, part 2, 43 (1989).

19. V.N. Fedorov Socio-economic infrastructure potential: content, assessment and analysis of development, ULGPU (2000).

20. M.G. Nikolaeva, N.V. Mordovchenkov, regional infrastructure and quality of life of the population: intersystem interaction, regional economy. Retrieved from https:/cyberleninka.ru/article/n/regionalnaya-infrastruktura-i-kachestvo-zhizninaseleniya-mezhsistemnoe-vzaimodeystvie, 2, 197 (2010).

21. L.V. Oshefnikova, the content of strategic planning and forecasting infrastructure support of entrepreneurial activity, modern problems of science and education. Retrieved from http://www.science-education.ru/ru/article/view?id=9363, 3, 51 (2013)

22. Infrastructure of Russia: development index 2020. Analytical review. Retrieved from https://infraone-research.ru/index_id/2020?index2020, September, 66 (2020).

23. Infrastructure of Russia: development index 2019. Analytical review. Retrieved from https://infraone-research.ru/index_id/2019?index2019, February, 66 (2019). 